DOI: 10.2478/v10141-009-0005-1

\title{
Hook to the Chin
}

\author{
Lev Kreft
}

Department of Philosophy, Faculty of Arts - University of Ljubljana, Slovenia

ABSTRACT

\begin{abstract}
Within historical avant-garde movements from the beginning of the $20^{\text {th }}$ century, a curious taste and fascination for boxing burst out, and developed later into the claim that art must become more similar to boxing, or to sport in general. This fascination with pugilism in the early stage of its popularity on the continent included such charismatic figures of the Parisian avant-garde as Arthur Cravan, who was Oscar Wilde's nephew, a pretty good boxer and an unpredictable organizer of proto-dada outrages and scandals.
\end{abstract}

After WWI, the zenith of artists' and intellectuals' love for boxing was reached in Weimar Germany. One of the well known examples connecting boxing with art was Bertolt Brecht with his statement that we need more good sport in theatre. His and other German avant-garde artists' admiration for boxing included the German boxing star May Schmeling, who was, at least until he lost his defending championship match against Joe Louis, an icon of the Nazis as well. Quite contrary to some later approaches in philosophy of sport, which compared sport with an elite art institution, Brecht's fascination with boxing took its anti-elitist and anti-institutional capacities as an example for art's renewal.

To examine why and how Brecht included boxing in his theatre and his theory of theatre, we have to take into account two pairs of phenomena: sport vs. physical culture, and avant-garde theatre vs. bourgeois drama. At the same time, it is important to notice that sport, as something of AngloSaxon origin, and especially boxing, which became popular on the European continent in its American version, were admired by Brecht and by other avant-garde artists for their masculine power and energy. The energy in theatre, however, was needed to disrupt its cheap fictionality and introduce dialectical imagination of Verfremdungseffect (V-effect, or distancing effect). This was "a hook to the chin" of institutionalized art and of collective disciplinary morality of German tradition.

KEYWORDS avant-garde, boxing, theatre, Bertolt Brecht

\section{Artistic Avant-Garde and Boxing}

There are always some coincidences which we would like to interpret as more than just coincidences. To speak about boxing and art in academic circles does not come as an ordinary everyday occasion. However, during my studies for this paper, after fighting with scarce but primordial and non-theoretical sources, two books on boxing and art appeared, both with their own theoretical, even philosophical and aesthetical interest in this relationship. The first, written by Kasia Boddy - Boxing. A Cultural History, appeared in 2008, and represents an apprehensive report on boxing's cultural status, context and its cultural consequences, including the times before and 
especially after WWI, when America (i.e., the USA) was treated by European cultural pessimists and avant-garde optimists as the future, and boxing was part of that embraced Americanized future for Europe: especially in Germany. A quote from Bertolt Brecht's journal from 1920 can prove this: “...how boring Germany is! It's a good average country, its pole colours and surfaces are beautiful, but what inhabitants! - What's left? America!" [Boddy 2008, 228] This book is not only a great source of all kinds of information on boxing and culture, especially on the relationship between boxing and artists, it is at the same time an analytical account of these relationships from the $17^{\text {th }}$ century to the present day, which, perhaps, makes it the kind of book Stendhal spoke about when he said that there are books which everybody reads and uses, but rarely praises as they should be praised.

On the other side, and a bit later, appearing in 2009, there is David Scott's book The Art and Aesthetics of Boxing (with a well-advertised foreword by MIT editor and former boxer Roger L. Conover) which covers a more specific field of culture, that of the aesthetic aspect of boxing. He covers three fields: how aesthetic highlighting takes place, forms of artistic representation of boxing, and how writers revealed the aesthetic and symbolic potential of boxing, all these to present boxing in its semiotic and aesthetic as well as more general sporting and sociological aspects [Scott 2009, xxiiixxxii]. David Scott is an active boxer as well. His approach mentions the theatrical character of boxing on many occasions, including in the very last sentences of the book, but his artistic material includes lyrics and prose, painting and sculpture, and no theatre, which is a pity, because the dramatic dimension of boxing is acknowledged but not researched through the influence of boxing on theatre, which means that Bertolt Brecht, who introduced boxing in his plays and wrote fiction and essays on pugilism, is not even mentioned.

Arthur Cravan, Oscar Wilde's nephew (they never met, but he claimed that Oscar was still alive and that he visited him in Paris, but in reality they never met), a poet, anarchist and heavyweight boxing champion of France (who claimed his title without a single match to prove it), is one of the most fascinating characters of the early avant-garde, an icon of Dada and Surrealism, admired by Marcel Duchamp, Francis Picabia and André Breton alike. Before WWI, he published a journal Maintenant, writing all texts and poems by himself under different names, Oscar Wilde's signature included, and got involved in boxing fights from time to time to appear in front of the public and get some money, as he was constantly broke. His real artistic power was in his constant public appearances, artistic and boxing alike, which turned into provocations and scandals. His last performance was his death in Mexico in November 1918, when he disappeared at sea. There are many versions and interpretations of this event, ranging from suicide to tragic accident, but many did not believe that he really died, and he was seen after his presumed death appearing again at many different locations all over the world, hidden under this or that concocted and mysterious personality, the novelist B. Traven included. What impressed other avant-garde artists was that he invented and designed his life and his death, and turned his body into an artwork in itself. Two meters high, with a strong muscular body, the star of an early stage of continental boxing, he was the direct opposite of a modernist poet with his lyrical weakness and bohemian outlook. For avant-garde movements he represented anti-art, a strong pugilist body creating a space of physical fascination versus the decadent no-body of the institution of art. Another paradox: he represented exactly what Oscar Wilde never was. But Cravan's avant-garde boxing was only popular among avant-garde artists, and it was popular because it was so unpopular among members of higher culture who looked down upon such plebeian professionalism and entertainment with disgust ${ }^{1}$.

\footnotetext{
${ }^{1}$ To get more on Arthur Cravan, his artistic and boxing career, see: Arthur Cravan, »Before Dawn«, 2 Bit Poetry, no. 1 (August 1985), LETTERS, Toronto (his poetry); Arthus Cravan, Oeuvres. Poèmes, articles, lettres (Édition établie par Jean-Pierre Begot), Éditions Gérard Lebovici, Paris 1987 (his poetry, texts from his journal
} 
After World War I, boxing gained popularity among continental Europeans, gentlemen and ladies alike, but nowhere did it become such an object of fascination as in the post-war Weimar Republic. There were many boxing icons and heroes, but May Schmeling was by far the greatest, a real champion, not a dubious one like Arthur Cravan, who was in reality just the best boxer among avant-garde artists and the best avant-garde artist among boxers. Max Schmeling started his professional career in 1924, he was German and European light-heavyweight champion, and then German heavyweight champion (1928), world heavyweight champion (1930-32) and European heavyweight champion (1939-1943). What decorated his biography with a touch of a legend were his two matches with Joe Louis $(1936,1938)$, the first of which he unexpectedly won. After the war and when their careers were over, they became friends, and Max visited Louis frequently, helped him financially, even paying for his funeral in the end. Two legends together, and a saga of friendship between a German boxing hero and an African American champion who finally found himself without money and without the "friends" who had made millions from his boxing. How to explain the sudden popularity of boxing in Germany both in avant-garde artistic circles and among National Socialists?

In Alfred Flechtheim's guestbook (Flechtheim was a major art dealer of avant-garde art and publisher of "Der Querschnitt"), after one of his parties, Max Schmeling left his memento: "Artists grant me your favour, Boxing is also an art." [Schmelling 1977, 87] ${ }^{2}$ Avant-garde artists claimed that modern art with its autonomy and institutions, dwelling somewhere far away from everyday life, has nothing to do with life and has to be abandoned, even destroyed: to become part of life again, new art, or anti-art should follow the attractive example of sport in general and boxing in particular. National Socialists, quite on the contrary, planned and later executed the destruction of avant-garde art, but adored sport, boxing and especially Max Schmeling. As much as the Left of German society glorified Schmeling for his victory over the Italian Michele Bonaglia in 1928, because in this case democratic Weimar culture had defeated Fascist totalitarian culture, the extreme Right glorified his victory over Joe Louis in 1936 because in this case the German race proved its supremacy over the black race and American culture. Why was it that boxing was embraced as a cultural and political battlefield of such importance in post-WWI Germany?!

The common ground of both the artistic avant-garde and National Socialists, but not just of their diagnosis of European and Western civilization, was that modern civilization and culture had both failed. We have to understand the special meaning this differentiation between civilization and culture assumed in German fin-de-siècle academic, intellectual and artistic circles. Civilization was an ugly, prosaic and materialist creature of soulless progress which should get some sense and human end from high culture ${ }^{3}$. The experience of cultural decadence, but much more the experience of war

Maintenant, documents on his boxing career); 4 dada suicides, Atlas Press, London 2005 (including his article »To Be or Not to Be...American« which appeared on June 6, 1909 in L'Écho des Sports: »Today, in contrast, everyone is American, It is essential gto be American, or at least to look like you are one, which is exactly the same thing.«); María Lluisa Borràs, Arthur Cravan. Una Biografia, Quadernas Crema, Barcelona 1993 (his biography). A dicumentary Cravan vs. Cravan by Isaki Lacuesta appeared in 2002 (100 min.; María Lluisa Borràs appears here as well). Obviously, Arthur Cravan left his impact and memory in Barcelona where he stayed during the WW1, and arranged a boxing match with Jack Johnson, a sensational and memorable event (he lost, of course, but earned enough to leave Cataluña for the States).

2 "Künstler schenkt mir eure Gunst, Boxen ist doch auch eine Kunst." Quoted in David Bathrick, »Max Schmeling on the Canvass: Boxing as an Icon of Weimar Culture «, New German Critique, No. 51/1990, p.136

${ }^{3}$ Relationship between sport and civilization was ambiguous. On one side, there were those who claimed that sport is on the other side of civilization, in a similar position as culture and therefore an activity beyond necessity of everyday life and vulgar strive for money and power; on the other side were those who saw in sport's popularity just another proof that civilization, together with its culture and way of life in general, is sinking, as Titanic did. This contrarity of opinion is far from over, and was discussed in the 1960s already in Bero Rigauer's 
triggered the conclusion that civilization cannot be healed with culture because it shares the same terminal illness. Oswald Spengler's claim that the West had come to an end was only the most popular outcry of a common feeling. There was a radical difference between the avant-garde and fascism or National Socialism in other views, but here they had the same position. And there was, in spite of everything else being different, something more: there was a need for immediate action of a kind that only heroes can deliver. For the avant-garde, heroes are those who, already belonging to the future, physically and with their bodies engaged in struggle to destroy the continuity of the present with the past - to save the future. For National Nocialists, heroes are those who grow from German blood and German soil into bodies which can rouse the German people (Volk) to become aware of their destiny and to become masters of the whole world. A big difference, but in both cases being a hero does not mean having lofty ideas organized into a sublime poetic performative. It means getting physically involved, putting your own body at stake, vouching with your bodily presence that you are deadly serious. As a theoretician of contemporary art and its custodian Boris Groys begins his analysis of the hero as the central figure of fascist art theory: "The heroic act transforms the hero's body from a medium into a message." What comes to mind first as a distinction between an athlete and an intellectual is that for an athlete the body is the medium of his or her profession. But how can this body become a message? At this point, Bertold Brecht's insistence on more good sport in art is revealing.

\section{Mehr Guten Sport - More Good Sport}

"More good sport “ (Mehr Guten Sport) is a title of Brecht's text from 1926 which often comes to mind in connection with his revolutionary ideas on theatre [Brecht 1995, 31-34]. In our time, it was declared that there are no certain limitations between (high) art and all other culture [Jameson 1991], that art and sport are both part of performances [Schechner 2002] and that they both turned into spectacle [Debord 1990]. Still, even in our times of body-art [Jones 1998] and bio-art ${ }^{5}$, a demand that we need more good sport in theatre still sounds like a paradox which calls for an explanation, but our explanation is ready: there is no insurmountable difference between sport and art because they both adapt to and belong to global commodity culture. In the post-WWI cultural and intellectual atmosphere in Germany, however, Brecht's paradoxical statement had another flavour, that of a double diagnosis and double healing method. The diagnosis is that of a battle between German institutionalized culture, and the healing method is a cultural turn. On the one side there was the militaristic physical culture of the Turnverein, which should be abandoned in favour of individualist competitive professional sport following the American example ${ }^{6 ;}$ on the other hand boring institutionalized bourgeois theatre which should be abandoned in favour of new theatre of pleasurable and educative critical social engagement. As an important part of pre-war German culture, bourgeois

polemics against Carl Diem (see Bero Rigauer, Sport and Work (transl. Allen Guttmann), Columbia University Press, New York 1981 (German original 1969).

${ }^{4}$ Groys, B. (2008) »The Hero's Body. Adolf Hotler's Art Theory«, Art Power The MIT Press, Cambridge (Mass) and London, p. 131.

${ }^{5}$ See: http://www.bio-art.com , and many other sites on the web, including definitions which say that bio-art is production of the works of art from the living matter in research laboratories.

${ }^{6}$ On Brecht's attitudes on the States - America, see a comprehensive study by Patty Lee Parmalee Brecht's America, Miami University and Ohio State University Press 1981. On Brecht and Berlin, including atmosphere of sport, see Wolf von Eckhardt and Sunder L. Gilman Bertolt Brecht's Berlin. A Scrapbook of the Twenties, University of Nebrasca Press, Lincoln and London 1993 (first printing 1975). For Brecht, among numerous books and studies, John Willett's classic book Brecht in Context. Comparative Approaches, Methuen, London 1998 (revised edition; first published 1984) in perhaps the best introduction to Brecht's fascinations. On his formation, see Hans Otto Münsterer The Young Brecht, Libris, London 1992 (German original 1963). 
theatre and physical culture were accused of being responsible for the decadence of civilization and the decline of the West. In German national bourgeois theatre following a doctrine introduced by Lessing [Lessing 1962] an image of morality of domestic bourgeois life should be dramatically threatened and always victoriously re-established as human and German national virtue. After so many years of modern bourgeois German theatre ${ }^{7}$, including its development into a subscription system (abonnement) and establishment of workers' theatres which followed the same bourgeois aesthetics and shared with it a similar abonnement system, and especially after the fall of modern culture and its presumed values as a consequence of the WWI cultural crisis, this theatre became predictable and boring, its audience was passive and uninvolved, and its actors seemed to be just doing a job without any passion or involvement. Or, it did not touch its audience any more, after the hell they had been in and through, and the chaos in which they lived after the war. It still represented life, but in the eyes of new audiences it represented what was defeated in WWI. The division between stage and audience became an obstacle for Aristotelian effects, and Aristotelian effects seemed to be long outdated anyway. Physical culture was a similar case. Embedded in nationalist culture, it derived its components and overall structure and values from military exercises, but covered its function with myth and ideology of formation of beautiful and virtuous men and women, with bodies always prompt and ready to be sacrificed for the national community and minds prepared to listen to orders. Its proper public appearance was at festivals and parades, not in sport competitions, and it did not allow for individualism or for free expression of physical abilities. Physical culture was a disciplinary and social hygienic project which included national bodies into a general formation of national collective. After WWI, these values were not in fashion with so-called sacrificed generations of those who spent the best years of their youth at some of the fronts of Europe, or who went to school to be taught about ideals and values which everyday life denied and destroyed. Sport, however, was another story. In German eyes it arrived in Europe together with the Americans, just like jazz. This included boxing, a typical individual fighting skill with a struggle between two wills to win, and a possibility of a knockout always present in spite of new rules which introduced points instead of the earlier "box until one drops" principle. It was what WWI proved not to be: a noble struggle of two wills, minds and bodies determined to win, but respecting the opponent's manhood and skills, with real sweat, pain and blood, and with involvement of a passionate audience from all strata of society, both sexes and all age groups. Sport was seen as something happening on the other side of society, where strict rules of behaviour did not apply. There were old media covering sport, but not a media frenzy which happened much later. If you wanted to be included in sport, you either practised it or had to go to watch it live. It was not just something alternative to collective physical culture; it was far removed from aristocratic values of elite, including those of Olympic sport. Under this comparison, it had more to do with Alpine climbing, car racing, transatlantic flying, and similar challenges and risks which could prove that great achievements are still possible, as are strong determination and deep passions. The culture of the West has no use for pre-war institutionalised art any more. What it needs is a hook to the chin.

It was a common conclusion that the culture of modernity is not a solution for the troubles of civilisation, but part of the problem,. Those who did not accept Oswald Spengler's prediction that the West is on its way down had to look for an alternative cultural model which would contradict the established one, as did Bertolt Brecht or, for instance, Oscar Pannwitz, a man who invented postmodernism and started a pan-European movement. An alternative to physical culture was sport, and an alternative to modern art was cinematography, but Brecht insisted on radical change in theatre as well.

\footnotetext{
${ }^{7}$ Lessing's Hamburgische Dramaturgie was at first published in 1767/68 as periodical criticism of theater in Hamburg where he was engaged as dramaturg after he was expelled from Berlin and its Academy for his quarrels with Voltaire; a year later (1769) it appeared in book form as well. This book, which however depends very much on previous Diderot's works on theater, is often considered to be the bible of new theater.
} 
But to be successful Brecht had to re-introduce some passion and some reality to theatre, not only for its audience but for its actors and other stake-holders as well. Sport in general and boxing in particular could show them the right direction. In boxing both athletes and their public find a lot of joy, pleasure and delight, including passionate execution of skill and involvement of the public. For something to be aesthetic and have an artistic value, it has to be attractive to the senses, it has to trigger strong emotions, and it has to keep a promise of pleasure, joy and delight. The slogan "More good sport!" is about that, and about more than just that: it underlines the fact that dramatic conflict has to be as real as life itself for all who are involved in its presentation.

Social structure of the audience is very important for Brecht. He claims that the bourgeois elite theatre's regular visitors belong to the upper strata of society, and present themselves there more or less because it is a place which belongs to their collective identity. Quite contrarily, Brecht dislikes this kind of social division of theatrical space, and rejects the stalls' dramatic taste, their attentiveness and their tendency to get emotionally lost in fiction. He prefers mixed audiences of all strata of society and mixed sexes, ages and races. Such audiences were not common before WWI, with the exception of motion pictures which were thoroughly examined from the moral point of view for that reason. Masses enjoying boxing were of that kind, massive mixed audiences in big halls with one thing on their mind: to get what they wanted - a battle of wills and passions, bodies in action, and some real life drama. And what they wanted, they got, quite in contrast with traditional theatre. This was what theatre needed: an urban mixture of people. This mixture was the reason that movies were called "democratic art" [Jowett, 1976]. Boxing seemed to be even more democratic, because it had an appeal of plebeian taste for loosening the grip of ordinary rules of behaviour, and an ability to push people over the line. Conventions, good behaviour and do-nots of theatre do not apply here. This mixed audience of boxing, an massive urban bunch of human bodies absorbed in a dramatic event, was what Brecht loved and tried to transport into theatre. And this was also the dangerous mass of modernity, a necessary product of modernity but what modern times were and still are afraid of: subjects out of subjection to rules and control, out of their mind but fully inhabiting and enjoying their bodies, an erotic image of passionate absorption in event, capable of who knows what, seeing with a touch of camaraderie each other watching and enjoying the same thing, and each one seeing himself or herself unleashed and unplugged from ordinary social mechanisms of self-control and obedience.

Brecht believed kalokagathia to be in conflict with such an understanding of sport, because it was an attempt to pacify and perhaps even erase this out-of-control situation with the help of morality. He also felt sport might develop in the wrong direction if it became pressurized to follow useful and rational ends. In his texts "Sport und Geistiges Schaffen" (1926) and "Die Krise des Sportes" (1928) he turns attention to processes which seek general recognition for sport as a socially useful and rational activity. This means, he thinks, that sport is getting clean of its subversive components, which are substituted by morally acceptable goals, while the whole field of public sport is constrained by more and more rules and by more and more scientific measurement of results. Taken together, these tendencies put sport in a strait-jacket of social acceptability. In the first text, he begins by rejecting beautiful-and-virtuous as an aesthetic and moral ideal of sport because even an ugly or unhealthy body can do spiritually great things (some of this comes from his own health condition and physical inabilities), before proceeding to attack preachers of hygiene immediately afterwards: "Sport aus Hygiene ist etwas Abscheuliches" (Sport for the sake of hygiene is something disgusting) [Brecht 1995, 35]. Hygienic purposes are those which use sport for healthy reasons, muscle-building, keeping beautiful appearance and acceptable body weight, and many other similar reasons which turn sport into just a tool for non-sport use, while all its authentic desires, passions and delights born from conflict and playfulness disappear. This disappearance of the autonomous core of sport is an announcement of its crisis: "Man könnte eine Menge verlockende Argumente dafür anführen, dass der 
Sport in den Schülen gelehrt, von der Akademie kontrolliert und von der Nation zum Kulturgut arhoben warden müsse. Soll man es?" [Brecht 1995, 97] - We could cite a lot of attractive arguments in favour of sport being taught in schools, controlled by universities and installed by the nation as a cultural good. But should we?

When sport was still far from being controlled and pacified, boxing even more so, Brecht sensed what was coming, and declared himself an enemy of prevailing developments in sport which turned sport into this kind of over-institutionalised global entertainment industry we have. Cultural goods, however, were his initial target already in the Twenties: "Kurz: ich bin gegen alle Bemühungen, den Sport zu einem Kulturgut zu machen, schon darum, weil ich weiss, was diese Gesellschaft mit Kulturguten alles treibt, weil und solange er riskant (ungesund), unkultiviert (also nicht geselschaftfähig) und selbstzweck ist." [ Brecht 1995, 98] In brief: I stand against all efforts to turn sport into a cultural good, firstly because I know what this society does with cultural goods, while sport is risky (unhealthy), uncultured (therefore socially not useful) and an end in itself. That is a kind of theatre, against its traditional formula, Brecht wants: unhealthy, not socially useful, and uncultured. Society is in such a state that socially useful cultural goods cannot help it; on the contrary, only those activities which are socially unacceptable may produce a healthy shock. It is not for sport or theatre to please society.

In his text "Die Todesfeinde des Sport" (1928/29; Sport's Deadly Enemies) Brecht summarizes. There are two kinds of deadly enemies of sport: those who want to turn it into a hygienic movement for the healthy mind in a healthy body, and those who, with the help of scientific drive of rationalisation and precise measurement, want to confine it to a rule-obedient and exactly measured noble art. Again, boxing is a prime example, because its attractiveness comes from the "box until one drops" principle, and not from the socially pacified collecting of points.

According to Brecht, sport and theatre have an ability to reach beyond the ordinary, literally, beyond the established social order. Of course, artistic modernism of the fin-de-siècle worshipped trans-social power of the art, but what it had in mind was the artistic nobility of the sublime, something which everyday life of modern civilisation is deprived of. What Brecht claims is that art as a sublime accessory cultivating vulgar everyday life kills exactly its ability to become a performative which opens horizons of social possibilities different from those which are already established. Traditional art of theatre confirms what already is, even when it seems to be critical. The source of extraordinary power is in the unhealthy, ignoble and self-sufficient which is to be found in sport, but not just in any kind of sport: boxing is here a primary example of a primordial form of plebeian masculine combat which emanates an aura of aesthetic power. This means, by the way, even if German has no distinction of the English pair of concepts, that Brecht called for a more conflicting game in a theatrical play, where, besides performers on the stage entangled in their dramatic narrative, the audience is drawn to the conflict, taking positions, expressing feelings and calculating about the outcome. This kind of public so common to sport spectatorship could bring real life into the theatrical space. This means that all involved in this kind of theatre are taking a risk, sharing this risk, because something of utmost human and social value is at stake.

That is what Brecht had in mind when he repeatedly recommended boxing as a paradigm for new theatre, when he demanded more good sport in art, and when he warned against deterioration of sport into hygienic and pure rational, mathematically and rationally controlled contest. It might sound too daring to say that his theory of the Verfremdung effect is a knockout approach to theatre, to overthrow theatrical fiction which holds the audience in an entertaining and pacifying illusion, and to turn attention to the total risk involved in its drama. 
There is one additional reason for boxing: it is a man's sport, a sport where concrete manhood is at stake. Not that victory means that you are a man, and defeat that you are not. In boxing, fighters enter into a ring which symbolises the four sides of the masculine universe of will, conflict, skill and nobility. You risk all these just entering into a combat which, according to Brecht, should still, in spite of new rules, continue until one fighter or the other drops down. That is also the point made by the "Hook to the Chin" short story. Freddy, an emerging champion, goes to bar before his most important match, and feels an urge to drink a glass of beer, but his manager advises him not to, because it would be sheer madness just before the fight. Freddy obeys this prohibition, but feels that he is not equal to other men around the table any more, and that his passion for boxing has become an obligation and an obstacle. He leaves the bar in a bad mood. After the match, again with beer in their hands, a company of friends with their elbows in puddles of beer get a report:

Although we were all pretty clear in our minds about the outcome of the fight, I nevertheless asked for the sake of completeness, "Yes, and..."

"He was knocked out in the second round. What else did you expect?"

"Nothing, but why was it, do you think, that he was k.o.'d?"

"Quite simple. When we went out of the bar I knew Freddy had a low opinion of himself."

"That is pretty clear," I said, "but what, in your opinion, should a man in Freddy's position have done?"

The man emptied his glass and said, "A man's got to do what a man's got to do. In my opinion. You know, caution is the mother of the knock-out." [Brecht 1983, 71]

\section{REFERENCES}

4 dada suicides. (2005). London: Atlas Press.

Bathrick, D. (1990). Max Schmeling on the Canvass: Boxing as an Icon of Weimar Culture. New German Critique, no 51, pp. 113-136.

Boddy, K. (2008). Boxing. A Cultural History. London: Reaktion Books.

Borràs, M. L. (1993). Arthur Cravan. Una biografia. Barcelona: Quadernas Crema.

Brecht, B. (1983). Bert Brecht Short Stories. London and New York: Methuen.

Brecht, B. (1995). Der Kinhaken und andere Box- und Sportgeschichten. Frankfurt am Main: Suhrkamp.

Cravan, A. (1985). Before Dawn. 2 Bit Poetry, no 1, Toronto.

Cravan, A. (1987). Oeuvres. Poèmes, articles, letrer. Paris: Éditions Gérard Lebovici.

Debord, G. (1990). Comments on the Society of the Spectacle. London: Verso.

Eckhardt, W. von, and Gilman, S. L. Bertolt Brecht's Berlin. A Scrapbook of the Twenties. Lincoln and London: University of Nebraska Press.

Groys, B. (2008). Art Power. Cambridge (Mass.) and London: The MIT Press.

Jameson, F. (1991). Postmodernism, or, the Cultural Logic of Late Capitalism. London: Verso.

Jones, A. (1998). Body Art/Performing the Subject. Minneapolis and London: University of Minnesota Press.

Jowett, G. (1976). Film: The Democratic Art. Boston: Little and Borwn.

Lessing, G. E. (1962). Hamburg Dramaturgy. New York: Dover. 
Münsterer, H. O. (1992). The Young Brecht. London: Libris.

Paramalee, P. L. (1981). Brecht's America. Miami: Miami University and Ohio State University Press.

Rigauer, B. (1981). Sport and Work. New York: Columbia University Press.

Schechner, R. (2002). Performance Studies. An Introduction. London: Routledge.

Schmeling, M. (1977). Erinnerungen. Frankfurt am Main: Ullstein.

Scott, D. (2009). The Aesthetics of Boxing. Lincoln and London: University of Nebraska Press.

Willett, J. (1998). Brecht in Context. Comparative Approaches. London: Methuen. 